\title{
Adherence to nutritional recommendations and sociodemographic variables in patients with diabetes mellitus
}

\author{
Adesão às recomendações nutricionais e variáveis \\ sociodemográficas em pacientes com diabetes mellitus \\ Adhesión a las recomendaciones de nutrición y variables \\ sociodemográficas en pacientes con diabetes mellitus
}

Maria Lucia Zanetti ${ }^{1}$, Clarissa Cordeiro Alves Arrelias ${ }^{2}$, Rosana Cristina Franco², Manoel Antônio dos Santos ${ }^{3}$, Flávia Fernanda Luchetti Rodrigues ${ }^{2}$, Heloisa Turcatto Gimenes Faria ${ }^{4}$

${ }^{1}$ Universidade de São Paulo, Escola de Enfermagem de Ribeirão Preto, Departamento de Enfermagem Geral e Especializada, Ribeirão Preto, SP, Brazil.

${ }^{2}$ Universidade de São Paulo, Escola de Enfermagem de Ribeirão Preto, Programa de Pós-Graduação em Enfermagem Fundamental, Ribeirão Preto, SP, Brazil.

${ }^{3}$ Universidade de São Paulo, Faculdade de Filosofia, Ciências e Letras de Ribeirão Preto, Ribeirão Preto, SP, Brazil.

${ }^{4}$ Colégio Integrado Libertas de São Sebastião do Paraíso, MG, Brazil.

\section{ABSTRACT}

Objective: To determine if there is a relationship between adherence to nutritional recommendations and sociodemographic variables in Brazilian patients with type 2 diabetes mellitus. Methods: Cross-sectional observational study using a stratified random sample of 423 individuals. The Food Frequency Questionnaire (FFQ) was used, and the Fisher's exact test was applied with 95\% confidence interval $(\mathrm{p}<0.05)$. Results: Of the 423 subjects, $66.7 \%$ were women, mean age of 62.4 years $(\mathrm{SD}=11.8), 4.3$ years of schooling on average $(\mathrm{SD}=3.6)$ and family income of less than two minimum wages. There was association between the female gender and adherence to diet with adequate cholesterol content (OR: 2.03; CI: 1.23; 3.34), between four and more years of education and adherence to fractionation of meals (OR: $192 \mathrm{CI}: 1.19 ; 3.10$ ), and income of less than two minimum wages and adherence to diet with adequate cholesterol content (OR: 1.74; CI: 1.03, 2.95). Conclusion: Adherence to nutritional recommendations was associated with the female gender, more than four years of education and family income of less than two minimum wages.

\section{DESCRIPTORS}

Diabetes Mellitus; Food Habits; Nutrition, Public Health; Primary Care Nursing; Family Health. 


\section{INTRODUCTION}

For most patients with diabetes mellitus (DM), adherence to healthy food is a constant challenge in the treatment, and following the eating plan is usually perceived as prohibitive, restrictive and far from the usual pattern ${ }^{(1-2)}$.

The Brazilian Society of Diabetes (BSD) recommends an individualized eating plan, according to the daily caloric needs, physical activity and drug therapy for each patient ${ }^{(3)}$. In addition to the quantitative recommendations, the daily diet should be fractionated into six meals, comprising three main meals and three intermediary snacks ${ }^{(3-5)}$. The dietary recommendations for people with diabetes should be focused on individual needs, taking into account the stage of the life cycle, nutritional diagnosis, dietary habits, the system of beliefs and socio-cultural values, as well as the metabolic profile and use of medications. They must also be consistent with the standards set for the general population ${ }^{(3)}$.

A cross-sectional study with 609 adults with DM conducted between 2008 and 2010 evaluated the adherence to nutritional recommendations reported by the subjects, according to the recommendations of the European Association of Diabetes (EASD), the American Diabetes Association (ADA) and the Mediterranean Diet. This research showed that only $48.7 \%$ of the subjects adhered to the EASD recommendations, $46.3 \%$ to the ADA recommendations and $57.4 \%$ to the Mediterranean Diet ${ }^{(6)}$.

A study conducted in Jordan with adult and elderly patients with type 2 diabetes mellitus (T2DM) has shown that adherence to diet is low even when guided by a nutritionist and based just on few days a week ${ }^{(7)}$. Another study conducted in Botswana, Africa, evaluated the rates of adherence to diet using the nutritional recommendations of the health professional in the diet proposed by the Approach to Stop Hypertension (DASH). It also found unsatisfactory adherence rates ${ }^{(8)}$.

It is complex to investigate the relationship between the variables involved in the phenomenon of treatment adherence because such relation is not well established yet. Some of the factors stand out, such as gender, age, education and income, among others. Studies show a relationship between adherence to drug treatment and the female gender ${ }^{(9-11)}$, old age $^{(9,12)}$ and education ${ }^{(9)}$.

In the international literature, cross-sectional studies suggest that gender, age, education, marital status and occupation are related to adherence to dietary recommendations ${ }^{(6,13-14)}$.

However, evidences of adherence to nutritional recommendations are still scarce in the national context ${ }^{(15)}$. The contribution of sociodemographic variables in adherence to diet of middle-aged adults and the elderly must be investigated taking into consideration that diabetes is a progressive condition and, therefore, can bring different demands of adherence to diet throughout the disease course.

The following question arises when considering the individualized food plan: What is the relationship between sociodemographic variables and adherence to nutritional recommendations for individuals with DM? Given the above, this study aimed to determine whether there is relationship between adherence to nutritional recommendations and sociodemographic variables in Brazilian patients with T2DM.

\section{METHOD}

This is a sectional observational study conducted from February to December 2010 in the city of Passos (state of Minas Gerais - MG), southeastern Brazil. The population consisted of 1,406 patients with T2DM registered in 17 primary care health centers.

The sample size calculation was performed using the formula for transverse studies of infinite population, based on a conservative adherence prevalence of $50 \%$, which enabled the highest possible quantitative. The sample size calculation resulted in 421 people with T2DM. The sample was increased by $20 \%$ considering possible sampling loss resulting from denials, hospitalizations, dropouts, erroneous and/or unavailable information.

The study participants were patients aged over 18 years, using oral drug therapy for T2DM control, able to understand and answer the questions of the survey instrument (observed by the researchers during their monitoring in the institutions), and who agreed to participate in the study by signing the Informed Consent form. Women diagnosed with gestational diabetes and patients who were using insulin were excluded.

For data collection were selected 505 people, of whom 14 were not found at home, 12 refused to participate in the study, six denied the diagnosis of T2DM, 25 were excluded because they were using insulin, 11 had changed address, five did not use pharmacological therapy for T2DM, three due to visual impairment, one for hearing impairment and five died, totalling 82 sample losses. Thus, the stratified random sample included 423 people with type 2 diabetes who met the inclusion criteria.

Two instruments were used for data collection: a questionnaire with sociodemographic variables (gender, age, years of education and family income) and the Food Frequency Questionnaire (FFQ), proposed and validated in $2002^{(16)}$. The FFQ allows to evaluate the consumption of ten food groups according to the number of times, unit and size of portions consumed.

Data collection was carried out by field researchers previously selected and trained. Sociodemographic and FFQ data were obtained through direct interviews carried out in the homes of patients. The average length of each interview was 40 minutes.

Data were organized in a Microsoft Excel spreadsheet through double entry and validation for controlling possible errors in translating the information. The variables were coded in accordance with the response and, whenever possible, were categorized to facilitate the analysis and understanding of results.

The Dietsys software, version 4.0 was used for entry of the FFQ data. The U.S. National Cancer Institute has developed this program, through which were obtained the mean total caloric value (TCV) consumed by each individual, the consumed amount of fiber and cholesterol in milligrams, as well as the percentage of carbohydrates, protein, 
total fat and saturated fat in relation to TCV. The calculation of TCV and macronutrients was based on the coding of responses about consumption frequency of each food.

For the analysis, we used descriptive statistics to characterize the sample and determine the prevalence of adherence to diet. The adherence to nutritional recommendation was assessed according to each item of diet composition for patients with T2DM, as recommended by the Brazilian Society of Diabetes (Chart 1$)^{(3)}$. In the FFQ, it was considered as adherence when patients followed at least three of the six BSD nutritional recommendations, i.e., consumption of total carbohydrates, dietary fiber and fractionation of meals. These three recommendations were chosen because of their direct relationship with glycemic control of patients with DM.

Chart 1 - Nutritional composition of the diet plan and fractionation of meals according to the BSD - São Paulo, SP, Brazil, 2014.

\begin{tabular}{|c|c|}
\hline Diet composition & Diabetes mellitus \\
\hline Carbohydrates (CHO) & 45 to $60 \%$ of TCV \\
\hline $\begin{array}{l}\text { Total fat } \\
\text { Monounsaturated fat } \\
\text { Polyunsaturated fat } \\
\text { Saturated fat }\end{array}$ & $\begin{array}{l}\text { Aproximately } 30 \% \text { of TCV } \\
\text { Complete individually } \\
\text { Up to } 10 \% \text { of TCV } \\
<7 \% \text { of TCV }\end{array}$ \\
\hline Cholesterol & $<200 \mathrm{mg} /$ day \\
\hline Proteins & 15 to $20 \%$ of TCV \\
\hline Dietary fiber & Minimum of $20 \mathrm{~g}$ per day \\
\hline Fractionation of meals & 5 to $6 /$ day \\
\hline
\end{tabular}

The Fisher's exact test was applied to investigate the relationship between adherence to nutritional recommendations of the eating plan and sociodemographic variables. The quantification of association was measured using logistic regression models. The gross odds ratio (OR) was calculated with $95 \%$ confidence interval for each variable in relation to adherence. Statistical analyzes were performed using the $\mathrm{SAS}^{\circledR} 9.0$ statistical software. P values $<0.05$ were considered statistically significant. The project was approved by the Ethics Committee on Human Research of the University of São Paulo (protocol number 0990/2009).

\section{RESULTS}

Of the 423 patients with T2DM, the average age was 62.4 years (standard deviation: 11.8 ). There was a predominance of females (66.7\%), and 4.3 years of study on average (standard deviation: 3.6). Regarding family income, the salary of $69.6 \%$ of subjects was less than two minimum wages, with a median of $\mathrm{R} \$ 1,020$ (standard deviation: 5,077.6) (Table 1).

Regarding the nutritional composition of the diet plan and fractionation of meals according to $\mathrm{ADA}{ }^{(4)}$, the consumption of carbohydrates and proteins was within expected parameters for the majority of patients $(69.3 \%$ and $51.1 \%$, respectively). In relation to the adequate cholesterol content in the diet, $81.3 \%$ of patients reported consumption according to the recommendation.

On the other hand, $57.9 \%$ of patients reported high intake of saturated fat, mean of 7.5 (standard deviation: 2.3).
Most patients (92\%) did not reach the minimum recommended of dietary fiber consumption. Regarding the fractionation of meals, $78 \%$ reported having at least five meals a day, average of 3.9 (standard deviation: 1.0) (Table 2).

Table 1 - Numerical and percentage distribution of patients with T2DM according to sociodemographic variables - Passos, MG, Brazil, 2010.

\begin{tabular}{|c|c|c|c|}
\hline Variables & $\mathbf{N}$ & $\%$ & Mean (SD) \\
\hline \multicolumn{4}{|l|}{ Gender } \\
\hline Female & 282 & 66.7 & \\
\hline Male & 141 & 33.3 & \\
\hline Age & & & $62.4(11.8)$ \\
\hline$<60$ years & 162 & 38.3 & \\
\hline$\geq 60$ years & 261 & 61.7 & \\
\hline Years of study & & & $4.3(3.6)$ \\
\hline$\leq 4$ & 294 & 69.5 & \\
\hline$>4$ & 129 & 30.5 & \\
\hline Family income ${ }^{*}$ & & & $\begin{array}{c}1,020 \\
(5,077.6)^{* *}\end{array}$ \\
\hline$<1,530$ reais & 272 & 69.6 & \\
\hline$\geq 1,530$ reais & 119 & 30.4 & \\
\hline
\end{tabular}

Table 2 - Distribution of patients according to nutrients intake and fractionation of meals according to BSD recommendations - Passos, MG, Brazil, 2010.

\begin{tabular}{lccc}
\hline Food consumption & $\mathbf{N}$ & $\%$ & Mean (SD) \\
\hline Total carbohydrates (\%) & & & $51.9(7.8)$ \\
$<45 \%$ & 72 & 17.0 & \\
45 to $60 \%$ & 293 & 69.3 & \\
$>60 \%$ & 58 & 13.7 & \\
Saturated fat & & & $7.5(2.3)$ \\
$<7 \%$ & 178 & 42.1 & \\
$\geq 7 \%$ & 245 & 57.9 & \\
Cholesterol & & & $142.5(71.9)$ \\
$<200 \mathrm{mg}$ & 344 & 81.3 & \\
$\geq 200 \mathrm{mg}$ & 79 & 18.7 & \\
Protein & & & \\
$<15 \%$ & 123 & 29.1 & \\
15 a 20\% & 216 & 51.1 & \\
$>20 \%$ & 84 & 19.9 & \\
Fiber & & & \\
$>20 g r$ & 34 & 8.0 & \\
$<20 g r$ & 389 & 92.0 & \\
Fractionation of meals & & & \\
$\geq 5$ & 93 & 22.0 & \\
$<5$ & 330 & 78.0 & \\
\hline
\end{tabular}

By adopting the minimum significance level of 5\% (pvalue $<0.05$ ), was found an association between the female gender and adherence to diet with adequate cholesterol content (OR: 2.03; CI: 1.23; 3.34) (Table 3). 
Table 3 - Association between sociodemographic variables and adherence to nutritional recommendations - Passos, MG, Brazil, 2010.

\begin{tabular}{|c|c|c|c|c|c|c|c|c|c|c|c|c|}
\hline \multirow{2}{*}{ Variables } & \multicolumn{2}{|c|}{ Total carbohydrates } & \multicolumn{2}{|c|}{ Saturated fat } & \multicolumn{2}{|c|}{ Cholesterol } & \multicolumn{2}{|c|}{ Protein } & \multicolumn{2}{|c|}{ Fiber } & \multicolumn{2}{|c|}{ Fractionation } \\
\hline & n (\%) & p-value ${ }^{*}$ & n (\%) & p-value ${ }^{*}$ & n (\%) & p-value ${ }^{*}$ & n (\%) & p-value ${ }^{*}$ & n (\%) & p-value ${ }^{*}$ & n (\%) & p-value \\
\hline Gender & & 0.315 & & 0.917 & & 0.008 & & 0.151 & & 0.185 & & 0.083 \\
\hline Female & $200(68.3)$ & & $118(66.3)$ & & $240(69.8)$ & & $151(69.9)$ & & 19(55.9) & & $69(74.2)$ & \\
\hline Male & $93(31.7)$ & & $60(33.7)$ & & $104(30.2)$ & & $65(30.1)$ & & $15(44.1)$ & & $24(25.8)$ & \\
\hline Age & & 0.194 & & 0.613 & & 0.370 & & 0.272 & & 0.468 & & 0.334 \\
\hline $\begin{array}{l}<60 \\
\text { years }\end{array}$ & $106(36.2)$ & & $71(39.9)$ & & $128(37.2)$ & & $77(35.6)$ & & $15(44.1)$ & & $40(43.0)$ & \\
\hline $\begin{array}{l}\geq 60 \\
\text { years }\end{array}$ & $187(63.8)$ & & $107(60.1)$ & & $216(62.8)$ & & $139(64.4)$ & & 19(55.9) & & $53(57.0)$ & \\
\hline $\begin{array}{l}\text { Years of } \\
\text { study }\end{array}$ & & 0.170 & & 0.522 & & 0.343 & & 0.674 & & 0.333 & & 0.010 \\
\hline$\leq 4$ & $210(71.7)$ & & $127(71.3)$ & & $243(70.6)$ & & $148(68.5)$ & & $21(61.8)$ & & $54(58.1)$ & \\
\hline$>4$ & $83(28.3)$ & & $51(28.7)$ & & $101(29.4)$ & & $68(31.5)$ & & 13(38.2) & & $39(41.9)$ & \\
\hline Income $^{* *}$ & & 0.479 & & 0.221 & & 0.049 & & 0.325 & & 0.696 & & 1.000 \\
\hline $\begin{array}{l}<1,530 \\
\text { reais }\end{array}$ & $189(70.8)$ & & $120(73.2)$ & & $228(71.9)$ & & $136(67.3)$ & & $22(66.7)$ & & $61(70.1)$ & \\
\hline $\begin{array}{l}\geq 1,530 \\
\text { reais }\end{array}$ & $78(29.2)$ & & $44(26.8)$ & & $89(28.1)$ & & $66(32.7)$ & & 11(33.3) & & $26(29.9)$ & \\
\hline
\end{tabular}

An association was also found between education of four years or more and adherence to fractionation of meals (OR: 1.92; CI: 1.19; 3.10), and income of less than two minimum wages and adherence to diet with adequate cholesterol content (OR: 1.74, CI: 1.03; 2.95) (Table 4).

Table 4 - Logistic regression of variables associated with adherence to nutritional recommendations - Passos, MG, Brazil, 2010.

\begin{tabular}{|c|c|c|c|c|}
\hline \multirow{2}{*}{$\begin{array}{l}\text { Variables } \\
\text { Years of study }\end{array}$} & \multicolumn{4}{|c|}{ Fractionation of meals } \\
\hline & n (\%) & OR* & $\mathrm{Cl}^{* *}$ & p-value \\
\hline$\leq 4$ years & $54(58.1)$ & 1.00 & Reference & 0.0072 \\
\hline \multirow[t]{2}{*}{$>4$ years } & 39(41.9) & 1.92 & $(1.19 ; 3.10)$ & \\
\hline & \multicolumn{4}{|c|}{ LDL Cholesterol } \\
\hline Gender & n (\%) & OR & $\mathrm{Cl}$ & p-value \\
\hline Female & $240(69.8)$ & 2.03 & $(1.23 ; 3.34)$ & 0.0053 \\
\hline Male & 104(30.2) & 1.00 & Reference & \\
\hline \multicolumn{5}{|l|}{ Income } \\
\hline$<1,530$ reais & $228(71.9)$ & 1.74 & $(1.03 ; 2.95)$ & 0.0372 \\
\hline$\geq 1,530$ reais & $89(28.1)$ & 1.00 & Reference & \\
\hline
\end{tabular}

Patients with four or more years of education are more likely to fractionate meals than those with lower educational level $(\mathrm{OR}=1.92)$. The female gender and patients of lower income were more likely to have adequate LDL cholesterol level.

\section{DISCUSSION}

Despite the adopted methodological design not allowing causal relationships, the results indicate a relationship between the variables of gender, education and income, and the adherence to dietary recommendations. The results provide empirical evidence to support the planning of specific programs and represent new knowledge within the national context.
The evaluation of the food plan composition showed that most patients reported adequate intake of carbohydrates and proteins macronutrients, although studies indicate adherence to diet as one of the most critical points of treatment ${ }^{(1,17)}$.

In this sense, studies show that most patients with diabetes who received dietary guidelines do not follow the nutritional recommendations or abandon the prescribed food plan ${ }^{(2,7,18)}$. In terms of quality, the food composition of diet is an important requirement when considering feeding as a whole, because the total carbohydrate intake should include fruits, vegetables and whole grains that are fiber source ${ }^{(4)}$, which does not occur with refined carbohydrates such as breads, pastas and processed juices.

The low fiber intake found for most patients shows that, although the amount of carbohydrate intake is adequate, there was discrepancy in the quality of foods rich in fiber. According to the BSD recommendation, the fiber intake has beneficial effects on glucose and lipid metabolism, and acts favorably on maintenance of intestinal function ${ }^{(3)}$.

Regarding protein intake, the same discrepancy was found between the proper amount and the quality of food eaten, even though the reported amount is adequate (57.9\%). This finding may have reflected the high intake of saturated fat, since the main protein sources in diet are meat, milk, dairy products and legumes, and among them, meat, milk and dairy products are also sources of saturated fat. Thus, the results indicate that the quality of protein foods consumed has favored a high intake of saturated fat.

Adherence to appropriate fractionation of meals is recommended in the literature ${ }^{(19)}$. The data found in relation to fractionation were also highlighted in another study in the Brazilian context that showed an average dietary intake of three to four daily meals ${ }^{(20)}$. This suggests that $\mathrm{pa}^{-}$ tients with DM have difficulty with meeting the nutritional recommendations of fractionation of meals, an important step towards a better control of blood glucose levels. 
This study showed an association between the female gender and adherence to diet with adequate cholesterol content, as women presented a higher chance of this parameter. In this direction, a cross-sectional study conducted in Nigeria in 2010 found that women with diabetes showed higher adherence to treatment ${ }^{(13)}$. In contrast, a study in Nepal showed that compared to men, women are more likely to not adhere to nutritional recommendations ${ }^{(21)}$. Due to cultural differences in dietary patterns and the complexity of variables involved in adherence to dietary recommendations, the results are inconclusive in relation to gender. Thus, future studies should be conducted with similar methods to encourage comparisons.

There was no statistically significant difference in relation to age and the BSD nutritional recommendations. However, a cross-sectional study carried out in Spain between 2008 and 2010 with 609 adults with DM, showed that adherence to nutritional recommendations increased with age. Older adults showed greater adherence to nutritional objectives, probably due to cultural factors and the fact that it is easier to cook and eat at home in this period of life ${ }^{(6)}$.

Regarding education, in the present study, patients with four or more years of education showed greater chance to fractionate meals than those with lower educational level. The analysis of the association between four years and more of study and adherence to fractionation of meals confirmed the need for some level of education to understand the complexity of treatment. The food plan requires that patients understand the food components, their action in the body, which food contains the recommended nutrients and the correct consumption proportions, among others. Knowledge alone does not necessarily imply adherence to the prescribed treatment, but the lack of information can make treatment adherence difficult. People with higher levels of education tend to have greater knowledge and skills, facilitating the management of disease. Thus, the higher level of education is a variable that favors adherence to nutritional recommendations ${ }^{(8,14,22-23)}$.

In this sense, educational programs on diabetes should pay special attention to patients with low educational level. Health professionals need to plan educational activities considering the knowledge specificities of each patient.

An association between the income lower than two minimum wages and adherence to diet with adequate cholesterol content was found in the present study. Another study showed that patients with economic limitations have difficulty to purchase the foods prescribed in the diet plan ${ }^{(1,8)}$. Nevertheless, the results suggest that adherence to nutritional recommendations may occur even in people with modest incomes. In this sense, the dietitian can collaborate by elaborating an eating plan that meets the BSD nutritional recommendations regarding the cholesterol content in the diet, according to the particularities and specifics of each patient, including the variable of family income.

The results show that adherence to dietary recommendations was associated with the female gender, educational level higher than four years and family income of less than two minimum wages. This study contributes to the advancement of knowledge about the facilitating factors and the impediments to adherence to nutritional therapy in diabetes. However, the remaining challenges for future studies are to understand the nuances related to the strengths and weaknesses of patients with diabetes to meet the nutritional recommendations ${ }^{(23-24)}$.

Analyzing the pattern of the human diet is a challenging task, even with the aid of psychometric instruments, because data are obtained from self-report measures. When including middle-aged and elderly patients in the investigated sample, it adds up another difficulty related to cognitive limitations due to age. Note that this study did not include evaluation through a standardized instrument to detect possible cognitive impairment.

\section{CONCLUSION}

This study showed an association between the female gender and adherence to diet with adequate cholesterol content. It also found an association between four years and more of study and adherence to the fractionation of meals, and between income of less than two minimum wages and adherence to diet with adequate cholesterol content.

The study limitations are related to the cross-sectional design, which does not allow establishing relations of cause and effect between the variables investigated. However, it was possible to establish associations between some variables, opening new hypotheses of studies to be tested in future research. The comparison of this study results with those found in the literature was limited, considering the methodological differences and the instruments used for data collection, especially with regard to the instruments used to collect dietary data and the various adherence cutoff parameters.

This study investigated the relationship of the variables of gender, age, educational level and income with adherence to each nutritional recommendation. On the other hand, most studies available in the literature investigated the variables according to the general classification of adherence. Given this peculiarity, it was difficult to find studies to make comparisons with the results found in the present study. As a suggestion, future studies should investigate the adherence to a diet plan according to the various age groups of the population, since diabetes has glycemic control specificities for each stage of the life cycle.

Objetivo: Verificar se há relação entre a adesão às recomendações nutricionais e variáveis sociodemográficas de pacientes brasileiros com diabetes mellitus tipo 2. Métodos: Estudo observacional seccional, com amostra aleatória estratificada constituída por 423 indivíduos. 
Utilizou-se o Questionário de Frequência de Consumo Alimentar. Aplicou-se o Teste Exato de Fisher com intervalo de confiança de 95\% (p-valor<0,05). Resultados: Dos 423 sujeitos, 66,7\% eram mulheres, média de idade 62,4 (DP=11,8) anos, média de anos de estudo de 4,3 (DP=3,6) e renda familiar inferior a dois salários mínimos. Foi encontrada associação entre sexo feminino e adesão à dieta com adequado teor de colesterol (OR:2,03; IC:1,23;3,34), entre quatro anos e mais de estudo e adesão ao fracionamento das refeições (OR:1,92; IC:1,19;3,10), renda inferior a dois salários mínimos e adesão à dieta com adequado teor de colesterol (OR:1,74; IC:1,03;2,95). Conclusão: A adesão às recomendações nutricionais foi associada ao sexo feminino, escolaridade superior a quatro anos e renda familiar inferior a dois salários mínimos.

\section{DESCRITORES}

Diabetes Mellitus; Hábitos Alimentares; Nutrição em Saúde Pública; Enfermagem de Atenção Primária; Saúde da Família.

\section{RESUMEN}

Objetivo: Verificar si hay relación entre la adhesión a las recomendaciones de nutrición y las variables sociodemográficas de pacientes brasileños con diabetes mellitus tipo 2. Métodos: Estudio observacional seccional, con muestra aleatoria estratificada constituida de 423 individuos. Se utilizó el Cuestionario de Frecuencia de Consumo Alimentario. Se aplicó el Test Exacto de Fisher con intervalo de confianza del 95\% (p-valor<0,05). Resultados: De los 423 sujetos, el 66,7\% eran mujeres, promedio de edad de 62,4 (DP=11,8) años, promedio de años de estudio de 4,3 ( $\mathrm{DP}=3,6)$ y renta familiar inferior a dos sueldos mínimos. Se encontró asociación entre sexo femenino y adhesión a la dieta con adecuado contenido de colesterol (OR:2,03; IC:1,23;3,34), entre cuatro años y más de estudio y adhesión al fraccionamiento de las comidas (OR:1,92; IC:1,19;3,10), renta inferior a dos sueldos mínimos y adhesión a la dieta con adecuado contenido de colesterol (OR:1,74; IC:1,03;2,95). Conclusión: La adhesión a las recomendaciones de nutrición estuvo asociada con el sexo femenino, escolaridad superior a cuatro años y renta familiar inferior a dos sueldos mínimos.

\section{DESCRIPTORES}

Diabetes Mellitus; Hábitos Alimenticios; Nutrición en Salud Pública; Enfermería de Atención Primaria; Salud de la Familia.

\section{REFERENCES}

1. Pontieri FM, Bachion MM. Crenças de pacientes diabéticos acerca da terapia nutricional e sua influência na adesão ao tratamento. Ciênc Saúde Coletiva. 2010;15(1):151-60.

2. Ribas CRP, Santos MA, Zanetti ML. Representações sociais dos alimentos sob a ótica de pessoas com diabetes mellitus. Interam J Psychol. 2011;45(2):255-62.

3. Sociedade Brasileira de Diabetes. Diretrizes da Sociedade Brasileira de Diabetes 2014-2015. São Paulo: AC Farmacêutica; 2015.

4. American Diabetes Association. Nutrition principles and recommendations in diabetes. Diabetes Care. 2009;32 Suppl 1:513-61.

5. American Diabetes Association (ADA). Standards of medical care in diabetes-2014. Diabetes Care. 2014;37:S14-S80.

6. Muñoz-Pareja M, León-Muñoz LM, Guallar-Castillón P, Graciani A, López-García E, Banegas JR, et al. The diet of diabetic patients in Spain in 2008-2010: accordance with the main dietary recommendations: a cross-sectional study. PLoS ONE. 2012;7(6):e39454.

7. Khattab M, Khader YS, Al-Khawaldeh A, Ajlouni K. Factors associated with poor glycemic control among patients with type 2 diabetes. J Diabetes Complications. 2009;24(2):84-9.

8. Ganiyu AB, Mabuza LH, Malete NH, Govender I, Ogunbanjo GA. Non-adherence to diet and exercise recommendations amongst patients with type 2 diabetes mellitus attending Extension II Clinic in Botswana. Afr J Prim Health Care Fam Med. 2013;5(1):1-6.

9. Baquedano IR, Santos MA, Teixeira CRS, Martins TA, Zanetti ML. Factors related to self-care in diabetes mellitus patients attended at Emergency Service in Mexico. Rev Esc Enferm USP [Internet]. 2010 [cited 2014 Oct 17];44(4):1017-23. Available from: http://www.scielo.br/ pdf/reeusp/v44n4/en_23.pdf

10. Freitas RWJF, Araújo MFM, Marinho NBP, Damasceno MMC, Caetano JA, Galvão MTG. Factors related to nursing diagnosis, ineffective self-health management, among diabetics. Acta Paul Enferm. 2011;24(3):365-72.

11. Hong JS, Kang HC. Relationship between oral antihyperglycemic medication adherence and hospitalization, mortality, and healthcare costs in adult ambulatory care patients with type 2 diabetes in South Korea. Med Care. 2011;49(4):378-84.

12. Zhu VJ, Tu W, Marrero DG, Rosenman MB, Overhage JM. Race and medication adherence and glycemic control: findings from an operational health information exchange. AMIA Annu Symp Proc. 2011:1649-57.

13. Uchenna O, ljeoma E, Pauline E, Sylvester O. Contributory factors to diabetes dietary regimen non adherence in adults with diabetes. World Acad Sci Eng Technol. 2010;4(9):644-51.

14. Mumu SJ, Saleh F, Ara F, Afnan F, Ali L. Non-adherence to life-style modification and its factors among type 2 diabetic patients. Indian J Public Health. 2014;58(1):40-4.

15. Villas-Boas LCG, Foss MC, Foss-Freitas MC, Torres HC, Monteiro LZ, Pace AE. Adesão à dieta e ao exercício físico das pessoas com diabetes mellitus. Texto Contexto Enferm. 2011;20(2):272-9.

16. Ribeiro $A B$, Cardoso MA. Construção de um questionário de frequência alimentar como subsídio para programas de prevenção de doenças crônicas não transmissíveis. Rev Nutr. 2002;15(2):239-45.

17. Inzucchi SE, Bergenstal RM, Buse JB, Diamant M, Ferrannini E, Nauck M, et al. Management of hyperglycemia in type 2 diabetes: a patient-centered approach: position statement of the American Diabetes Association (ADA) and the European Association for the Study of Diabetes (EASD). Diabetes Care. 2012;35(6):1364-79.

18. Davison KAK, Negrato CA, Cobas R, Matheus A, Tannus L, Palma CS, et al. Relationship between adherence to diet, glycemic control and cardiovascular risk factors in patients with type 1 diabetes: a nationwide survey in Brazil. Nutr J. 2014;13:19. 
19. Franz MJ, Powers MA, Leontos C, Holzmeister LA, Kulkarni K, Monk A, et al. The evidence for medical nutrition therapy for type 1 and type 2 diabetes in adults. J Am Diet Assoc. 2010;110(12):1852-89.

20. Cotta RMM, Reis RS, Batista KCS, Dias G, Alfenas RCG, Castro FAF. Hábitos e práticas alimentares de hipertensos e diabéticos: repensando o cuidado a partir da atenção primária. Rev Nutr. 2009;22(6):823-35.

21. Shrivastava SR, Shrivastava PS, Ramasamy J. Role of self-care in management of diabetes mellitus. J Diabetes Metab Disord. 2013;12(14):3-5.

22. Gherman A, Schnur J, Montgomery G, Sassu R, Veresiu I, David D. How are adherent people more likely to think? A meta-analysis of health beliefs and diabetes self-care. Diabetes Educ. 2011;37(3):392-408.

23. Hernandez-Tejada MA, Lynch CP, Strom JL, Strom JL, Egede LE. Effect of perceived control on quality of life in indigent adults with type 2 diabetes. Diabetes Educ. 2012;38(2):256-62.

24. Lima ACS, Araújo MFM, Freitas RWJF, Zanetti ML, Almeida PC, Damasceno MM. Risk factors for Type 2 Diabetes Mellitus in college students: association with sociodemographic variables. Rev Latino Am Enfermagem. 2014;22(3):484-90. 